\title{
Availability of Entrepreneurial Leadership Skills for Sports Supervisors in Youth and Sports Institutions and Their Relationship with Emotional Intelligence "Field Study"
}

\author{
Ass.Prof: Mahmoud Seddik Abdel Wahed \\ Assistant Professor at King Saud University
}

In recent years scientists have noticed that attention to the traditional view of the intelligence is no longer limited to the cognitive perspective only where psychologists have found the importance of the emotional side of the human because of the increased impact conscience in human life and is inseparable from thinking and then there is a full conviction that there is no duplication (Gardner, Salovi, Mayer, 1990) and Coleman (1995) find that they agree that traditional tests of intelligence will not give a complete picture of the behavior of the individual and not enable us to test the predicting and success the future,

And in his work, and in his life in general has emerged a lot of queries that called for the importance of linking the cognitive and emotional side is that you may find a person mental intelligence high but not successful in his life and another person of moderate intelligence but successful in His life may also find a group of equal people in IQ but their performance rates are unequal.

All this has prompted psychologists to search for an element or field that has not been studied, examined or tested by or that the traditional theory has ignored and through which all these differences The contradictions are emotional intelligence. Pfeiffer, Steven I.:2001, 138142))

Hence, the importance of emotional intelligence, especially at the beginning of the third millennium, where the society faces many problems related to political, social, cultural and economic.

There is no doubt that the solutions to most of these problems that cause distress and concern to society is that the individual possesses not only well-developed intellectual abilities, but also have social and emotional skills that integrate with intellectual and practical skills to solve these current problems. People and the ability to harmonize them effectively and all this contributed to attention to emotional intelligence. (Komiya, 2022: 139)

In other words, attention must be given to the feelings or emotional aspects of the individual as a means of the individual's compatibility with the successive and conflicting variables that surround us based on the feelings of the individual and his emotions are the most important influences in directing his behavior in general and his way of thinking and issuing the provisions and decisions in particular,

The precise and rapid perception of emotions allows for quick and precise emotional and behavioral reactions, because without this skill these responses tend to be delayed later and therefore inappropriate for the situation. In other words, the individual loses his sensitivity to the behavioral situation and is unable The challenges of human beings and human nature are influenced by emotions. Our emotions affect every single thing in our life more than the influence of thinking when it comes to our destinies, actions and actions.

It also emphasizes that feelings are necessary for thinking and thinking. The balance in this case overcome the emotional mind on the situation and sweep the logical mind on the grounds that there is, as Mahmoud Mansi Aklin one emotional and the other logical. (Mnsi, 2012: 346-348)

Human resources are becoming increasingly competitive in all institutions that seek to win and compete in ever-changing markets. Therefore, interpersonal skills are one of the most important skills required in a manager, leader, or subordinate, and in all of our 
interlocking world, it is easy to deal with people But the real test is the ability to deal with the difficult moments, the anger, the tension that arises with others, especially in the work environment,

And extract the best for the benefit of both parties, as well as dealing with the different types of human personalities we face every day in the environment uncle , Golman (2001) noted that $76 \%$ of the skills that are important for success in work and professional life are emotional skills, the job of the entrepreneur and a human professional function with their characteristics, and require diverse abilities and personality, technical and general, Capacity.

With the scientific progress in all types of business, there is a growing need to rely on competent individuals to carry out the work. Any manager or head of any organization that sets certain characteristics or technical elements is a criterion for choosing the entrepreneur.

:( ) The great motivation that he wants to achieve, and the holding of things, and the love of competition.

$:(r)$ Ability to work hard and diligent.

$:(r)$ Independence and set their own goals.

:( ₹)Strong driving ability. (Al-Sakarna, 2008: 12)

In addition to this, self-understanding, problem solving, change management, crisis management, understanding the emotions of others, communication and communication with others, managing differences and conflicts, managing negotiation, managing the organization of work, The entrepreneur must be effective in his work, and for the construction of entrepreneurs, an effort must be made by the institutions concerned to prepare these groups of schools, universities, youth centers and non-profit institutions in order to give these individuals the characteristics of the entrepreneur and prepare him intellectually, psychologically and spiritually. (Sultan, 2015: 103)

With the growing global interest in entrepreneurship and its role in achieving sustainable development, it was necessary to pay attention to the study of the leading person as the main driver of entrepreneurial work. There is a great deal of studies on the characteristics of the leading person in an attempt to develop a general framework of personality,

The academic and training institutions strive to provide students with these characteristics in an effort to build a conscious generation that recognizes the importance of having the skills, knowledge and abilities it needs to start pioneering work. (Al-Shaikh et al., 2009: 109) The main question of the study: What is the relationship between emotional intelligence and functional skills of the entrepreneur in sports institutions?

\section{Objectives of the study:}

-To identify the statistical differences between the averages of the degrees of entrepreneurship that are attributed to the gender variable (male and female) on the scale of the entrepreneurial skills and dimensions (creativity, teamwork, motivation for achievement, good planning)

-To identify the statistical differences between the averages of the degree of entrepreneurship attributed to the gender variable (males and females) on the scale of emotional intelligence and its dimensions (self-awareness, emotional management, mental empathy, social skills)

-Identify the statistical differences between the averages of the entrepreneurial grades attributable to the variable of experience (1-10 years), (11-20 years) (21-30 years) on the emotional intelligence scale and its dimensions (self-awareness, emotional management, mental empathy, skills. Social)

-There is a significant correlation between emotional intelligence and its dimensions (selfawareness, emotional management, mental empathy, social skills) and the entrepreneurial skills and dimensions (creativity, team work, motivation for achievement, good planning) 


\section{The importance of studying:}

-The importance of this study derives from the importance of Emotional Intelligence. One of the important topics that has been and continues to receive great attention from those interested in this field.

The progress of societies and the development and continuation of their organizations depends mainly on the emotional and emotional side of the leaders and subordinates. In sports institutions.

- The importance of this study stems from the importance of the subject that it presents. Leadership is one of the main issues that aim at sustainable development in all societies.

The leading person with innovative ideas helps his society achieve economic growth as he seeks self-employment for himself and others. Through the provision of creative products or services that contribute to satisfying the needs of members of society on the one hand, and achieve excellence on the other hand.

- This study is important because it is looking at a very important axis for institutions and their employees alike, namely the focus on the functional skills of workers in sports institutions, which is rarely studied from a public relations perspective.

- The study is important because it provides new information and results on the role of emotional intelligence in developing the functional skills of entrepreneurs in sports institutions.

\section{The limits of the study:}

Spatial boundaries: The study was implemented by the Directorate of Youth, Sports and Youth Centers in Asyut

\section{Time Limits:}

The study was applied in the first semester of the academic year $2016-2017$

Human Density: The study will be applied to a sample of entrepreneurs in the Directorate of Youth, Sports and Youth Centers in Asyut, 169 of whom are males (130 sports specialists) and females (39) with a temporal age ranging from 25-55 years with an average age of 38 years

\section{Methodological limits:}

The researcher will use the descriptive approach because it is appropriate for the current study.

\section{Terminology of study:}

\section{First: Functional Skills:}

As the methods, skills and knowledge needed by the workers to do their work well and in order to achieve the best level of the objectives of the institution they work in. (Procedural definition)

\section{Second Entrepreneur:}

The entrepreneur has defined him as the initiator who accepts success and failure and has the spirit of risk, clear vision, ability to plan and discover opportunities, adopt new ideas, and have the ability to manage resources, employees and assets to make them valuable. For profit and growth.

\section{Third: emotional intelligence:}

The researcher defines the procedure as "a set of interrelated social, personal and emotional factors or abilities that affect the overall ability of the individual to adapt effectively and actively to the demands of life and to confront its pressures،

\section{Previous studies:}

1-The study of Yacou and Schumacher (2010): The study aimed at identifying the factors that lead to feeling happy or uncomfortable at work. The sample of the study consisted of members of the faculty of postgraduate studies.

The study found that the factors causing the satisfaction of work or what is called $\mathrm{He}$ pointed out that satisfying these needs and the services required by the organization to its 
employees lead to a high degree of satisfaction with work and improve performance, such as the development of functional skills, cooperation in work, emotional participation،

2- The study of Farha, Najat Mahmoud (2013): The study aimed to compare the reality of the process of delegation of authority for the female sector in Saudi universities and its relation to the development of functional skills in university universities.

The study sample consisted of a sample of heads of academic and administrative departments in some Saudi universities. There are significant differences between the Saudi universities and the study society in the aspects of delegating the authority of delegating integrated tasks for female sections such as planning, decision making،

3- The study of Al-Rashidi, Mohamed Awad (2014):

The objective of the study was to identify the role of public relations in enhancing the functional skills of university employees. The sample of the study consisted of the employees of Kuwait University in all their specialties. Public relations in the promotion of administrative communication between the different departments of the employees of Kuwait University by sex, and the results for the benefit of males, the absence of statistically significant differences in the extent of the contribution of public relations in the promotion of administrative communication between different sections of the workers.

4- Bar-On et al. (2003): The study aimed at addressing the effect of emotional intelligence and self-efficacy in decision-making. The study applied to a sample of faculty members in universities.

The study concluded that emotional intelligence and its dimensions are positively related to self-efficacy. Emotional intelligence and self-efficacy positively influence decision-making.

- - The study of Hartsfield (2003) The study aimed to know the effects of emotional intelligence and self-efficacy on the performance of leaders in management, and the sample of the study (124) managers from some companies in the United States, and the results of the study that emotional intelligence is one of the strongest predictors and then self-efficacy The spiritual aspect of successful leadership.

\section{Study hypotheses:}

:( ) There are statistically significant differences between the averages of the degree of the entrepreneur attributed to the gender variable (male and female) on the scale of the entrepreneurial skills and dimensions (creativity, teamwork, motivation for achievement, good planning)

$:(r)$ There are no statistically significant differences between the averages of the degree of the entrepreneur attributed to the gender variable (males and females) on the scale of emotional intelligence and its dimensions (self-awareness, emotional management, mental empathy, skills)

$:(1 \cdot-r)$ There are statistically significant differences between the averages of the degrees of the entrepreneur due to the variable of experience (1-10 years), (11-20 years) (21-30 years) on the scale of the entrepreneurial skills and dimensions (creativity, teamwork, motivation) For achievement, good planning)

$:(\varepsilon)$ There is a significant correlation between emotional intelligence and its dimensions (self awareness, emotional management, mental empathy, social skills) and the entrepreneurial skills and dimensions (creativity, teamwork, motivation for achievement, good planning) to her.

\section{Study Procedures:}

First: Study Sample:

The study tools were applied to a sample of entrepreneurs in sports institutions (65 male and female) aged 25-55 years with an average age of 38 years. Table (1) shows the sample of the study. 
Table (1) Sample of study (male - female), average age of sample

\begin{tabular}{|c|c|c|c|}
\hline Average of age & Age & Number & Gender \\
\hline \multirow{3}{*}{$r \wedge$} & $00-r_{0}$ & $r r$ & Male \\
\cline { 2 - 4 } & $00-r_{0}$ & $r r$ & Female \\
\cline { 2 - 4 } & & $T 0$ & Total \\
\hline
\end{tabular}

Second: Study Tools:

-Measuring the functional skills of the entrepreneur in sports institutions. (Researcher preparation)

-The measure of emotional intelligence of the leaders of sports institutions. (Researcher preparation)

:( ' )The functional skills scale of the leading sports institutions:

-The researcher has prepared the functional skills scale among the entrepreneurs in the sports institutions. The researcher has followed the following steps in constructing the scale: Operational Definition Functional Skills: The methods, skills and knowledge needed by employees to do their work well in order to achieve the best level of the objectives of the institution in which they work.

\section{(A): Scale dimensions:}

The researcher determined the dimensions of the functional skills as contained in the current scale based on

1) (Some of the measures that dealt with the functional skills scale include: Ansari, Issa (2005), Al-Sakarna, Bilal (2008), Aadi, Maher (2008) Dimensions include motivation for achievement, planning, teamwork, creativity

\section{)B) - Formulation of standard vocabulary:}

From previous sources, based on the definition of each dimension of the functional skill scale, the researcher formulated a set of vocabulary that belongs to each dimension of the scale (54)

(C) Method of response to scale and grade estimation:

The choice of answers One of five answers is (always, often, neutral, rarely, never). The score is between 1 - 5 degrees per individual, always (five degrees), often (4 degrees) and neutral (3 degrees), the alternative rarely (two degrees), and never (one degree) if the unit is positive and vice versa if the unit is negative.

The psychometric indicators of the functional skill level of entrepreneurs in sports institutions.

First, the functional skills scale

First: Calculation of Stability Parameters:

*Calculate the stability of the half-way. The researcher used to calculate the stability of the test Sabermann Brown equation for the midterm segmentation and the results were as shown in the following table:

Table (2) Correlation coefficient and stability of the functional skill scale using the Saberman semiconductor split equation

\begin{tabular}{|c|c|c|}
\hline Stability coefficient & Coefficient of correlation & Questionnaire axis \\
\hline$\cdot, \wedge ৭$. & $\cdot, \wedge \cdot$, & $\begin{array}{c}\text { The motivation for } \\
\text { achievement }\end{array}$ \\
\hline
\end{tabular}




\begin{tabular}{|l|l|c|}
\hline$\cdot, 9 \Sigma \Upsilon$ &,,$\wedge \wedge 9$ & Planning \\
\hline$\cdot, \wedge \Sigma \varepsilon$ & $\cdot, \vee \curlyvee 9$ & Working within a team \\
\hline$\cdot, \wedge \wedge \uparrow$ & $\cdot, \vee 9 \cdot$ & administration creativity \\
\hline$\cdot, 9 \uparrow \varepsilon$ & $\cdot, 9 \uparrow \cdot$ & Total scale \\
\hline
\end{tabular}

The above table shows that the scale has a high degree of stability.

${ }^{*}$ Calculation of stability using the formula Alpha Kronbach

Table (3) Stability coefficient of the scale using the Alpha Kronbach equation

\begin{tabular}{|l|l|}
\hline Stability coefficient & Questionnaire axis \\
\hline$\cdot, \wedge 0 \cdot$ & The motivation for achievement \\
\hline$\cdot, \wedge \uparrow \vee$ & Planning \\
\hline$\cdot, \wedge \Sigma 0$ & Working within a team \\
\hline$\cdot, \wedge \wedge \uparrow$ & administration creativity \\
\hline$\cdot, 9 \uparrow \Upsilon$ & Total scale \\
\hline
\end{tabular}

The above table shows that the scale has a high degree of stability.

$(r)$ measure of emotional intelligence for sports entrepreneurs in sports institutions:

-The researcher has prepared the measure of emotional intelligence among entrepreneurs in sports institutions. The researcher has followed the following steps in constructing the scale:

\section{-Procedural definition of emotional intelligence:}

As a set of interrelated social, personal and emotional factors or capabilities that affect the overall capacity of the deaf teenager to adapt effectively and actively to the demands of life and to cope with their pressures.

These include the following dimensions: self-awareness (awareness of the entrepreneur with his emotions, emotions, self-understanding, self-esteem, selfconfidence), Self-understanding), managing emotions (controlling and controlling negative emotions, transforming negative emotions into positive ones, defeating anger and stress, controlling emotions and alertness of conscience), mental empathy (reading others' feelings, , Altruism, empathy), social skills (interacting with others positively, helping others avoid negative responses, influencing others, cooperating with others, social responsibility).

\section{A - Determination of dimensions of the scale:}

The researcher determined the dimensions of emotional intelligence as contained in the current measure based on:

:( ( )theoretical framework and previous studies with different definitions of emotional intelligence, and characteristics of the sample.

‘( ... r)Kharnoub, Fattoun (2011), Sharaf, Iman; Mohamed, Nemeh (2002); (2013)

In light of the previous sources, the researcher determine the dimensions of transformational leadership as a concept that includes a multi-dimensional (selfawareness, self-awareness, management of emotions, empathy, social skills)

\section{B - Formulation of the standard vocabulary.}

Through previous sources, and based on the definition of each dimension of emotional intelligence scale dimensions, the researcher has drafted a set of vocabulary that belong to each dimension of the scale and dimensions of (51) members. 
H) Method of answering the scale and estimating the score.

The examinee determines the degree to which the individual applies to him by choosing from five (always, often, neutral, rarely, never)

Temperature range Screened between 1 - 5 degrees for each individual, where he is given the alternative is always (five degrees), the alternative is often (4 degrees) neutral alternative (3 degrees), and the alternative is rarely (two degrees), and alternative never (one grade) if the individual is positive and vice versa if The individual was negative.

Mathematical indicators of the emotional intelligence measure for sports entrepreneurs in sports institutions.

\section{First: Calculation of Stability Parameters:}

*Calculate the stability of the half-way. The Sabermann Brown equation was used to calculate the stability of the test and the results were as shown in the following table:

Table (9) correlation coefficient and stability of the questionnaire using the Sabermann Brown semiconductor fraction

\begin{tabular}{|c|c|c|}
\hline Stability coefficient & Coefficient of correlation & Questionnaire axis \\
\hline$\cdot, V Y \cdot$ &., $07 \pi$ & Self awareness \\
\hline., 010 & $\cdot, \pi 70$ & Emotions \\
\hline., 101 & $\cdot, Y \backslash r$ & Sympathy \\
\hline$\cdot, 1 \leq 7$ & $\cdot, \cdot \vee 9$ & social skills \\
\hline$\cdot, 7 \cdot 9$ & $\cdot, \varepsilon r V$ & Total scale \\
\hline
\end{tabular}

The above table shows that the questionnaire is highly stable.

*Calculation of stability using the alpha-chromatography equation

Table (10) Stability coefficient of the questionnaire using the alpha-chromatography equation

\begin{tabular}{|c|c|}
\hline Stability coefficient & Questionnaire axis \\
\hline$\cdot, 797$ & Self awareness \\
\hline$\cdot, 0 \vee \wedge$ & Emotions \\
\hline$\cdot, 0 . \Upsilon$ & Sympathy \\
\hline$\cdot, r \wedge \uparrow$ & social skills \\
\hline$\cdot, \vee \uparrow ०$ & Total scale \\
\hline
\end{tabular}

\section{Calculation of the validity coefficients}

The validity of the meter has been calculated in the following ways:

*Content Validation: The researcher presented the vocabulary of the scale in its initial form and the number of (51) single (12) of the arbitrators of the specialists in the field of sports management Supplement No. (1) in order to judge:

A ) the extent of relevance and dimension of the dimension.

B) The extent to which the vocabulary belongs to each dimension of the scale.

C) the appropriateness of the vocabulary formulation for the study sample.

Through the observations and proposals of the arbitrators, the researcher modified the wording of some of the vocabulary of the scale as shown in the following table: 
Table (11) Vocabulary modified in the measure of emotional intelligence according to the opinions of the arbitrators

\begin{tabular}{|c|c|c|}
\hline No a & The phrase before modification & The phrase after modification \\
\hline 0 & $\begin{array}{l}\text { I do not affect with my sad emotions upon } \\
\text { decisions. }\end{array}$ & My sad emotions do not affect my decisions. \\
\hline$\wedge$ & $\begin{array}{l}\text { My self-esteem increases when I overcome a } \\
\text { bad habit }\end{array}$ & $\begin{array}{l}\text { When I overcome a bad habit, my self-esteem } \\
\text { increases. }\end{array}$ \\
\hline 10 & I am calm under any pressure I face. & When I have any pressure I am calm. \\
\hline r) & $\begin{array}{l}\text { Usually I can do what I need emotionally } \\
\text { and willingly. }\end{array}$ & $\begin{array}{l}\text { I can do what I need emotionally and } \\
\text { willingly. }\end{array}$ \\
\hline rч & $\begin{array}{c}\text { I am effective in listening to the problems of } \\
\text { others }\end{array}$ & I listen well to the problems of others \\
\hline rA & $\begin{array}{l}\text { I am able to read people's feelings from the } \\
\text { expressions of their faces. }\end{array}$ & $\begin{array}{l}\text { I can read the feelings of people from the } \\
\text { expressions of their faces. }\end{array}$ \\
\hline rq & $\begin{array}{c}\text { I am sensitive to the emotional needs of } \\
\text { others. }\end{array}$ & I feel the emotional needs of others. \\
\hline$r \varepsilon$ & I am in harmony with the feelings of others. & Incompatibility with the feelings of others \\
\hline$\leqslant 7$ & $\begin{array}{c}\text { I am always friendly when dealing with } \\
\text { others. }\end{array}$ & I smile when I deal with others. \\
\hline$\varepsilon \wedge$ & I am always ashamed of social attitudes. & I feel ashamed in social matters. \\
\hline 0. & I always denounce the opinions of others & $\begin{array}{l}\text { I condemn the opinions of others when } \\
\text { dealing with them. }\end{array}$ \\
\hline
\end{tabular}

And the researcher deleted by specifying the proportion of agreement less than $80 \%$, the individual will be deleted and Table (12) shows the proportions of the agreement of the arbitrators on the vocabulary of each dimension of emotional intelligence.

Study results and interpretation:

Results of the first hypothesis:

The first hypothesis is that there are statistically significant differences between the averages of the entrepreneur's grades due to the gender variable on the skills and dimensions of the entrepreneurial skill scale (creativity, team work, motivation for achievement, good planning) for males.

Table 16 shows the difference between males and females to identify functional skills and their dimensions

\begin{tabular}{|c|c|c|c|c|c|c|c|c|c|c|}
\hline Statem & \multicolumn{3}{|c|}{ Female } & & & & \multirow{2}{*}{$\begin{array}{c}\text { Degree } \\
\text { of } \\
\text { freedom }\end{array}$} & \multirow{2}{*}{$\begin{array}{c}\text { T } \\
\text { Tabular } \\
\text { value }\end{array}$} & \multirow{2}{*}{$\begin{array}{c}\mathbf{T} \\
\begin{array}{c}\text { Calculated } \\
\text { value }\end{array}\end{array}$} & \multirow{2}{*}{$\begin{array}{c}\text { Level of } \\
\text { significance }\end{array}$} \\
\hline level & $\mathrm{N}$ & M & $\mathrm{E}$ & $\mathrm{N}$ & M & $\mathrm{E}$ & & & & \\
\hline $\begin{array}{c}\text { The motivation } \\
\text { for } \\
\text { achievement }\end{array}$ & \multirow{5}{*}{ Tr } & $\varepsilon, r_{0}$ & $\cdot r \leq \varepsilon$ & & r,07 & $\cdot, \Gamma \leq \Gamma$ & \multirow{5}{*}{ Tr } & \multirow{5}{*}{$r, \ldots$} & $9,1 \wedge \varepsilon$ & \multirow{5}{*}{ significant } \\
\hline Planning & & $\varepsilon, \mu q$ & $\cdot, r V T$ & & r,OV & $\cdot, \leqslant \pi \leqslant$ & & & $\wedge, \wedge \wedge$ & \\
\hline $\begin{array}{c}\text { Working } \\
\text { within a team }\end{array}$ & & $\varepsilon, r r$ & $\cdot, \leqslant 0$ & Mr & $r, 00$ & • & & & $v, r 00$ & \\
\hline $\begin{array}{c}\text { administration } \\
\text { creativity }\end{array}$ & & $\varepsilon, r$ & $\cdot, \leq \varepsilon$ & & $r, 0 \leqslant$ & $\cdot, r \wedge$ & & & $v, \leqslant 01$ & \\
\hline Total scale & & $\varepsilon, r \leqslant$ & $\cdot, r$ & & $r, 07$ & 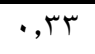 & & & $q, \cdot \vee \wedge$ & \\
\hline
\end{tabular}


The table above shows a statistically significant difference between males and females in functional skills on the scale as a whole and its dimensions in favor of males.

\section{Interpretation of the results of the first hypothesis:}

The results of Table (16) indicate that there is a statistically significant difference between the average score of the entrepreneurs in the sports institutions (males and females) on the scale of the functional skills and their dimensions (motivation for achievement planning - work within the team - administrative innovation) (2014) due to the delegated authority to delegate integrated tasks to male sections such as planning, decision making, management innovation،

Results of the second hypothesis:

\begin{tabular}{|c|c|c|c|c|c|c|c|c|c|c|}
\hline Stat & \multicolumn{3}{|c|}{ Male } & \multicolumn{3}{|c|}{ Female } & \multirow{2}{*}{$\begin{array}{c}\text { Degree } \\
\text { of } \\
\text { freedom }\end{array}$} & \multirow{2}{*}{$\begin{array}{c}\text { T } \\
\text { Tabular } \\
\text { value }\end{array}$} & \multirow{2}{*}{$\begin{array}{c}\mathbf{T} \\
\text { Calculated } \\
\text { value }\end{array}$} & \multirow{2}{*}{$\begin{array}{c}\text { Level of } \\
\text { significance }\end{array}$} \\
\hline $\mathbf{e}$ & $\mathrm{N}$ & M & & & & $\mathrm{E}$ & & & & \\
\hline Self awareness & \multirow{5}{*}{ 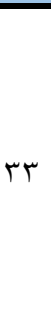 } & $\varepsilon, 01$ & $\cdot, r_{94}$ & \multirow{5}{*}{ rt } & $\varepsilon, \leqslant 9$ & $\cdot, 491$ & \multirow{5}{*}{ זדי } & \multirow{5}{*}{$r, \ldots$} & $\cdot, r 0 \leq$ & \multirow{5}{*}{$\begin{array}{c}\text { Not } \\
\text { significant }\end{array}$} \\
\hline Emotions & & $\varepsilon, 1$. & • سז,. & & $\varepsilon, 1$. & • & & & צחד, . & \\
\hline Sympathy & & $\varepsilon, \varepsilon \wedge$ & $\cdot, r \cdot q$ & & $\varepsilon, \varepsilon \vee$ & $\cdot, r \wedge r$ & & & $\cdot, \varepsilon \vee V$ & \\
\hline social skills & & ५, १V & $\cdot, r \leqslant r$ & & $\varepsilon, \cdot V$ & $\cdot, r 90$ & & & $\cdot \pi / V$ & \\
\hline Total scale & & $\varepsilon, Y V$ & . & & $\varepsilon, r^{\prime}$ & $\cdot, 1 \wedge 7$ & & & $\cdot, 1 \cdot 9$ & \\
\hline
\end{tabular}

The second hypothesis states that there are no statistically significant differences between the averages of the degrees of the entrepreneur attributed to the gender

variable (males and females) on the scale of emotional intelligence and its dimensions (selfawareness, emotional management, mental empathy, social skills)

Table 17 shows the difference between males and females to identify emotional intelligence and its dimensions

It is clear from the previous table that there is no statistically significant difference between males and females in emotional intelligence on the scale as a whole, and its dimensions

\section{Interpretation of the results of the second hypothesis:}

The results of Table (17) indicate that there are no statistically significant differences between the average score of the entrepreneurs in the sports institutions (males and females) on the scale of emotional intelligence and its dimensions (self-awareness, emotional management, mental empathy, social skills). The study agrees to some extent with the study of each study Raisarda (2003), and the study of Ahmed, Walid; Mti, Milad (2011), due to the nature of the work done by entrepreneurs that enable them, both male and female, to establish good and extended relations with The audience can thus understand others, empower them with self-awareness, and have social skills.

\section{Results of the third hypothesis:}

The third hypothesis is that there are statistically significant differences between the averages of the degrees of entrepreneurs attributed to the variable of experience (1-10 years), (11-20 years), (21-30 years) on the scale of functional skills and dimensions (motivation for achievement - planning - Team - Administrative Innovation)

Table (18) shows the results of the ANOVA analysis of the functional skill scale axes in terms of the variance of experience

\begin{tabular}{|c|c|c|c|c|c|c|}
\hline $\begin{array}{c}\text { Statement } \\
\text { Level }\end{array}$ & $\begin{array}{l}\text { Source of } \\
\text { Contrast }\end{array}$ & $\begin{array}{c}\text { Total } \\
\text { squares }\end{array}$ & $\begin{array}{c}\text { Degrees of } \\
\text { freedom }\end{array}$ & $\begin{array}{c}\text { Average of } \\
\text { squares }\end{array}$ & F value & $\begin{array}{c}\text { Level of } \\
\text { significance }\end{array}$ \\
\hline \multirow{2}{*}{$\begin{array}{c}\text { The motivation for } \\
\text { achievement }\end{array}$} & $\begin{array}{c}\text { Between } \\
\text { groups }\end{array}$ & $r, .0 \leqslant$ & r & $1, \cdot r V$ & \multirow{2}{*}{$\varepsilon, 10 \mathrm{~V}$} & \multirow{2}{*}{$\cdot, \cdot r}$. \\
\hline & $\begin{array}{l}\text { Within } \\
\text { groups }\end{array}$ & $10, r$. & Tr & $\cdot, r \leq V$ & & \\
\hline
\end{tabular}




\begin{tabular}{|c|c|c|c|c|c|c|}
\hline & Total sum & IV,TVE & $7 \varepsilon$ & & & \\
\hline \multirow{3}{*}{ Planning } & $\begin{array}{l}\text { Between } \\
\text { groups }\end{array}$ & r,I ro & r & זד. & \multirow{3}{*}{$r, \leqslant 01$} & \multirow{3}{*}{$\cdot, \cdot$ TN } \\
\hline & $\begin{array}{l}\text { Within } \\
\text { groups }\end{array}$ & $19, .91$ & Tr & $\cdot, r \cdot \Lambda$ & & \\
\hline & Total sum & $r, Y 17$ & $7 \varepsilon$ & & & \\
\hline \multirow{3}{*}{$\begin{array}{c}\text { Working within a } \\
\text { team }\end{array}$} & $\begin{array}{l}\text { Between } \\
\text { groups }\end{array}$ & $r, V \leqslant Y$ & r & $1, r v 1$ & \multirow{3}{*}{$\varepsilon, \vee 04$} & \multirow{3}{*}{$\cdot, \cdot 1 Y$} \\
\hline & $\begin{array}{l}\text { Within } \\
\text { groups }\end{array}$ & $I \vee, \wedge \vee \leqslant$ & Tr & $\cdot, \curlyvee \wedge \wedge$ & & \\
\hline & Total sum & $r \cdot, 71 T$ & $7 \varepsilon$ & & & \\
\hline \multirow{3}{*}{$\begin{array}{c}\text { administration } \\
\text { creativity }\end{array}$} & $\begin{array}{l}\text { Between } \\
\text { groups }\end{array}$ & 9זוד & r & $1, \wedge r$. & \multirow{3}{*}{$7, \wedge 70$} & \multirow{3}{*}{$\cdot, \cdots r$} \\
\hline & $\begin{array}{l}\text { Within } \\
\text { groups }\end{array}$ & سT & Tr & •, Y>0 & & \\
\hline & Total sum & $r \cdot, \cdot V r$ & $7 \varepsilon$ & & & \\
\hline \multirow{3}{*}{ Total scale } & $\begin{array}{c}\text { Between } \\
\text { groups }\end{array}$ & Y,TVA & r & q & \multirow{3}{*}{$0,7 Y \Lambda$} & \multirow{3}{*}{$\cdot, \cdots$} \\
\hline & $\begin{array}{l}\text { Within } \\
\text { groups }\end{array}$ & $1 \varepsilon, V O r$ & Tr & . & & \\
\hline & Total sum & $|V, \varepsilon \Psi|$ & $7 \varepsilon$ & & & \\
\hline
\end{tabular}

As shown in the previous table, all the axes and the scale as a whole are statistically significant. There are statistically significant differences between the averages of the degree of the entrepreneur in relation to the level of experience (1-10 years), (11-20 years), (21-30 years) (Motivation to achieve - planning - work within a team - administrative innovation). In the questionnaire as a whole and all the axes of the questionnaire, and to see which groups have the effect we are testing

Table (19) Shafi 's results for the post - comparisons to indicate the differences between the sample of the study in the questionnaires and the questionnaire as a whole according to the variable years of experience

\begin{tabular}{|c|c|c|c|c|c|}
\hline \multirow{2}{*}{ Axis } & \multirow{2}{*}{$\begin{array}{c}\text { Years of } \\
\text { Experience }\end{array}$} & \multirow{2}{*}{ SMA } & \multicolumn{3}{|c|}{ Direction of differences } \\
\hline & & & $1 \cdot-1$ & $r \cdot-11$ & $r \cdot-r)$ \\
\hline \multirow{3}{*}{$\begin{array}{c}\text { The } \\
\text { motivation for } \\
\text { achievement }\end{array}$} & $1 \cdot-1$ & $r, 7 \Lambda$ & & & $*_{\cdot,, \Sigma Y}$ \\
\hline & $r \cdot-11$ & $\varepsilon, \cdot r$ & & & \\
\hline & $r \cdot-r)$ & $\varepsilon, 1$. & & & \\
\hline \multirow{3}{*}{ Planning } & $1 \cdot-1$ & $r, V I$ & & & $* \cdot, \leqslant \varepsilon$ \\
\hline & $r \cdot-11$ & $\varepsilon,+1$ & & & \\
\hline & $r \cdot-r)$ & $\varepsilon, 10$ & & & \\
\hline \multirow{3}{*}{$\begin{array}{c}\text { Working } \\
\text { within a team }\end{array}$} & $1 \cdot-1$ & $r, T$ & & & $* \cdot,\{\Lambda$ \\
\hline & $r \cdot-11$ & $\varepsilon, \cdot r$ & & & \\
\hline & $r \cdot-r \mid$ & $\varepsilon, .9$ & & & \\
\hline \multirow{3}{*}{$\begin{array}{l}\text { administration } \\
\text { creativity }\end{array}$} & $1 \cdot-1$ & $r, 07$ & & & $*, 01$ \\
\hline & $r \cdot-11$ & $r, q 1$ & & & \\
\hline & $r \cdot-r)$ & $\varepsilon, 1 \varepsilon$ & & & \\
\hline \multirow{3}{*}{ Total scale } & $1 \cdot-1$ & $\overline{r, 7 T}$ & & & $* \cdot, \leqslant 9$ \\
\hline & $r \cdot-11$ & $\varepsilon, \cdots$ & & & \\
\hline & $r \cdot-r \mid$ & $\varepsilon, 1 Y$ & & & \\
\hline
\end{tabular}

${ }^{*}$ The differences between the averages are statistically significant for the 0.05 level. There are statistically significant differences in favour of the group (21-30) as a result of the increase in the arithmetic mean in all axes and the scale as a whole 
Interpretation of the results of the third hypothesis: The results of the third hypothesis indicate that there are statistically significant differences at the level of 0.05 between the level of experience (1-10 years) and the level of experience (11-20 years), and the level of experience (21-30 years) in the questionnaire as a whole Functional skills) and in all areas of the questionnaire. The study is consistent with the study of Scambel \& Stead (2011), AlRashidi and Mohammed Awad (2014). The differences in the level of experience are attributed to: the ability to work and acquire the skills that enable him to acquire functional skills

\section{Results of the fourth hypothesis:}

The seventh hypothesis states: There is a significant correlation between emotional intelligence and its dimensions (self-awareness, emotional management, mental empathy, social skills), functional skills and dimensions (motivation for achievement, planning, teamwork, managerial innovation)

Table (26) The correlation coefficient between functional skills and emotional intelligence

\begin{tabular}{|c|c|c|c|c|}
\hline \multicolumn{2}{|c|}{ Functional skills } & \multicolumn{2}{|c|}{ Emotional intelligence } & \multirow{2}{*}{$\begin{array}{l}\text { Coefficient of } \\
\text { correlation }\end{array}$} \\
\hline SMA & $\begin{array}{c}\text { standard } \\
\text { deviation }\end{array}$ & SMA & $\begin{array}{l}\text { standard } \\
\text { deviation }\end{array}$ & \\
\hline$r, 901$ & .,OYY & $\varepsilon, Y \vee T$ & $\cdot, Y)$. & **, , ror \\
\hline
\end{tabular}

It is clear from the table that there is a significant correlation between the functional skills and emotional intelligence of the leader of activity in sports institutions (** at level 0.01)

\section{Interpretation of the results of the seventh hypothesis:}

The results of the seventh hypothesis indicates the existence of a significant correlation between functional skills and emotional intelligence in the leader of activity in sports institutions, attributed to the importance of emotional intelligence, especially at the beginning of the third millennium, where we find the community facing many problems related to the political and social sphere and Cultural and economic. There is no doubt that the solutions to most of these problems that cause distress and concern to society is that the individual possesses not only well-developed intellectual abilities،

\section{Recommendations:}

-1- The need to hold seminars and workshops in the Directorate of Youth and Sports in Asyut to inculcate the values of diligence and patience are necessary conditions for success.

2-The need to hold workshops and youth centres in Asyut to develop the ability to identify the strengths and weaknesses in self.

3- The need to hold seminars and workshops in the Directorate of Youth and Sports in Asyut to install values of self-satisfaction when I appreciate the work of a realistic estimate and when I overcome a bad habit.

- Ethe need to hold seminars and workshops in the youth centres in Asyut skill to call positive emotions such as humour easily.

- - The need to hold seminars and workshops in the youth centres in Asyut about the control areas in my feelings help me to make important decisions in my life.

- 'The necessity of holding seminars and workshops at the Directorate of Youth and Sports in Asyut on how to face conflicts of life and feelings of anxiety and frustration .

\section{References:}

'Al-Ansari, Issa (2005) The functions of the head of the department and criteria for selection from the point of view of faculty members. Journal of the Faculty of Education, Al Azhar University. P. (C). Pp. 293-324.

r Golman (2000). Intelligence

${ }^{r}$ Emotional. (I). (Translation: Lili Jabali). Kuwait: The World of Knowledge. 
. Al kheder , Osman (2002). Emotional intelligence: is it a new concept?. Journal of Psychological Studies. Volume 12. 12. Issue (1), pp. 5-41.

- Jane Ann Craig (2005). It's not just how intelligent you are, but how to use your intelligence. (I). (Translated by Abdel-Elah El-Mallah). Riyadh: Obeikan Library.

`Kharnoub, Fettoun (2011). Emotional intelligence of some Sudanese universities workers . Khartoum Sudanese Journal. P (3). Pp. 58-72.

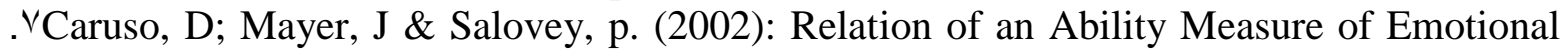
Intelligence to personality. Journal of personality Assessment. pp 306- 320.

.^Chun-sheng Yn; Ron, M .; Sardessai; June; Lu \& Jing - Hua (2006): Relationship of emotional intelligence with conflict.

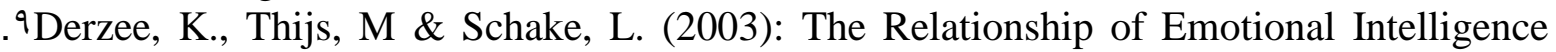
with Academic Intelligence and the big five. Eour peen Journal of personality, pp 103- 125.

. - Fernandez, Pablo. Ruiz, Desiree (2008): Emotional Intelligence in Education Electronic, Journal of research in Educational psychology, pp 423- 436. 